\title{
ISOLATION, CHARACTERIZATION AND VALIDATION OF LIPID DEGRADATION BY THE BACTERIAL ISOLATES FROM WASTE EDIBLE OIL CONTAMINATED SOIL
}

\author{
Iyengar $\mathrm{P}$, Iyengar $\mathrm{K}$, Balki A, Chichghare S \\ L.A.D.College for Women, Shankarnagar, Nagpur, Maharashtra, India
}

\begin{abstract}
Edible oil degrading microorganisms are useful for the remediation of edible oil spillage in the environment. Edible oil contains high lipid (oils and fats) concentration which inhibits the activity of microbes. But some microbes get acclimatized to the high lipid content and grow well in oil rich environment, degrading oil and feeding upon the lipid degradation products Bacterial strains were isolated to study the diversity of bacteria from waste edible oil contaminated soil sample which is collected from three different places and diluted up to four dilution and grew on nutrient media. The bacterial isolates were identified by morphological and physical observation. Differential media was used for identifying differential bacterial isolates and characterized by performing different biochemical tests. The strain was analysed with tributyrin, egg and oil to observe lipid degradation. The bacterial isolates that showed clearing of egg agar media is an indication of lipid degradation.
\end{abstract}

Key words - Edible oil, Bacterial strains, tributyrin and bacterial isolates

\section{INTRODUCTION:-}

Fats, oils and greases (FOGs) are released into the environment together with wastewater derived from the food processing industry, restaurants and kitchens or by accidental spill of oils [1].

Animal fats and vegetable oils are the main constituents of FOGs which contains a combination of glycerol and free fatty acids when hydrolysis takes place [2]. The wastewater contains lipids such as edible oil and long-chain fatty acids [3]. Lipids present in wastewater are difficult to remove and degrade because they are do not dissolve easily in water. They are known to inhibit methanogenic processes [4]. Lipid metabolism involves several steps including emulsifying and degradation. After degradation pathway, lipids are broken down into glycerol and fatty $\operatorname{acid}(\mathrm{s})$. The fatty $\operatorname{acid}(\mathrm{s})$ are then converted to acetyl-CoA via the beta oxidation pathway and finally enter the TCA cycle. Clogging of wastewater pipes often occurs in lipidcontaining wastewater treatment systems due to the lipids present in the wastewater [5].

Microorganisms isolated from soil and water samples have the ability to catabolise and remove wastewater lipids [6]. For environmental conservation, microbial functions have been investigated with respect to their use in treating lipid-containing wastewater [7][8]. Many studies have examined the microbial degradation of edible oils [9][10] and numerous microorganisms capable of degrading FOGs have been identified and may be potential candidates for bio augmentation products

The aims of this study were to (i) isolate the lipid-degrading bacteria from edible oil contaminated soil (ii) study characteristics of colonies, shape and lipid-degradation index and (iii) investigate the genetic diversity of lipid-degrading bacterial strains that have high ability of lipid-degradation in the environment

\section{MATERIALS AND METHODS:-}

Soil Sample:-

Samples were collected from the three different edible oil stores located in Itwar ibaazarpeth, (oil market of Itwari,Nagpur ) Nagpur .These soil samples are rich in edible oil.

Such soil samples were collected from the following locations

1. Shantilalchunnilal Tel Bhandar, Itwari, Nagpur

2. Chunnilal and Chunnilal TelBhandar, KiranaOli, Itwari, Nagpur

3. Anand Tel Bhandar, Itwari,Nagpur

The locations had no grasses growing on them and soil samples were collected at three different locations at each oil godown. The soils were characterized by hardened surfaces and blackish and brownish in colour. The edible oil contaminated soil samples were collected in plastic bags

Isolation of bacterial isolates:-

The samples were serial diluted up to 4 dilutions and grew on nutrient agar medium by spread plate method. The grown bacterial colonies were isolated on the basis of their appearance (size, colour and shape) and physical characters and sub-cultured on nutrient rich media at $37^{\circ} \mathrm{C}$

Identification of bacterial isolates:-

Gram staining: 
Isolates were observed for Gram reaction by Gram staining

Growth on Differential and selective media: The different isolates of bacterial culture was grown on different selective media like Mannitol salt agar, EMB agar and MacConkey agar to identify the bacterial isolates

Biochemical tests :

Biochemical tests were performed by using mother culture of bacterial isolates which were isolated from waste edible oil contaminated soil. The following biochemical tests were Results and Discussion

Tributyrin test is the test for lipid degradation and all the isolates obtained from the edible oil contaminated soil samples gave the tributyrin test positive with egg yolk as the tributyrin rich source. These organisms can be used for degrading oil spills that pose environmental hazards .Based on the biochemical tests for characterization Proteus vulgaris ,Pseudomonas aeruginosa, Staphylococcus aureus, Micrococcus luteus and Bacillus cereus were found to be the organisms involved in lipid degradation.

\section{REFRENCES:-}

[1] V. Cipinyte, S. Grigiskis and E. Baskys, "Selection of fat-degrading microorganisms for the treatment of lipid-contaminated environment," Biologija, , vol. 35, pp. 84-92, 2009.

[2] M.C. Cammarota, G.A. Teixeira, and D.M.G. Freire, "Enzymatic pre-hydrolysis and anaerobic degradation of wastewaters with high fat contents," BioTechnol.Letters, vol.23, pp.1591-1595, 2001.

[3] D. Sugimori, and T. Utsue, "A study of the efficiency of edible oils degraded in alkaline conditions by Pseudomonas aeruginosa SS219 and Acinetobacter sp. SS-192 bacteria isolated from Japanese soil," World J. Microbiol. Biotechnol., vol. 28(3), pp.841-848, 2013. doi:10.1007/s11274-011-0880-6.

[4] M. Hatamoto, H. Imachi, Y. Yashiro, A. Ohashi and H. Harada, "Diversity of Anaerobic Microorganisms Involved in Long-Chain Fatty Acid Degradation in MethanogenicSludges as Revealved by RNA-Based Stable isotope Probing," Appl. And Environ. Microbiology, vol. 73(13), pp.4119-4127, 2007. performed: carbohydrate test (lactose and dextrose ), citrate test, indole test, triple sugar iron agar test, methyl red test, VP test, hydrogen sulphide test, urease test, gelatin test, litmus test,

Tributyrin egg yolk agar test:

Tributyrin agar base and egg yolk was prepared and isolated bacterial culture were streaked on medium and incubated for $24 \mathrm{hr}$ at $37^{\circ} \mathrm{C}$ in incubator and were observed for lipid degradation

[5] D. Sugimori, M. Nakamura, and M. Mihara, "Microbial degradation of lipid by Acinetobacter sp. strain SOD-1," Biosci. Biotechnol.Biochem, vol.66(7), pp.1579-1582, 2002.

[6] D. Sugimori, M. Watanabe and T. Utsue, "Isolation and lipid degradation profile of Raoultellaplanticola strain 232-2 capable of efficiently catabolozing edible oils under acidic conditions," Appl. Microbiol. Biotechnol., vol. 97, pp;871-880, 2013.

[7] J.P. Canler, C. Roger and Ph. Duchene, "Aerobic biological treatment of grease from urban wastewater treatment plants," Water Sci. Technol., vol. 44, pp.219-226, 2001.

[8] Y. Wei, R.T.V. Houten, A.R. Borger, D.H. Eikelboom, and Y. Fan, "Minimization of excess sludge production for biological wastewater treatment," Water Res., vol. 37, pp.4453-4467, 2003.

[9] Y. Yamaoka, K. Takeno, H. Shinkawa, N. Noparatnaraporn and K. Sasaki, "Isolation of a thermotolerant photosynthetic bacterium, Rhodobacterspaeroides strain, NAT, and its capasity for oil and chemical oxygen demand removal at high temperatures," Biosci. Biotechnol.Biochem., vol. 72(6), pp.16011603, 2008.

[10] D, Tanaka, M. Takashima, M. Mizuta, S Tanaka, A. Sakatoku, A. Nishikawa, T. Osawa, M. Noguchi, S.I. aizawa and S. Nakamura, "Acinetobacter sp. Ud-4 efficiently degrades both edible and mineral oils: Isolation and charactization," Curr. Microbiol, vol. 60(3), pp.203-209, 2010. 
Table no. 1 showing gram reaction and growth on differenctial media

\begin{tabular}{|c|c|c|c|c|c|c|}
\hline \multirow{2}{*}{$\begin{array}{l}\text { SAMPLE } \\
\text { (Isolates) }\end{array}$} & \multirow{2}{*}{$\begin{array}{l}\text { AGAR SLANT CULTURAL } \\
\text { CHARACTERISTICS }\end{array}$} & \multirow{2}{*}{$\begin{array}{l}\text { GRAM } \\
\text { STAINING }\end{array}$} & \multicolumn{4}{|c|}{ DIFFERENCTIAL MEDIA } \\
\hline & & & MacConkey & Mannitol salt agar & $\begin{array}{l}\text { Starch } \\
\text { agar }\end{array}$ & EMB \\
\hline A & $\begin{array}{l}\text { thick light yellow white } \\
\text { abduntant viscous }\end{array}$ & $+\operatorname{rod}$ & purple & $\begin{array}{l}\text { no growth no colour } \\
\text { change }\end{array}$ & $\begin{array}{c}+ \\
\text { growth }\end{array}$ & transparent \\
\hline B & $\begin{array}{l}\text { thin grayish growth } \\
\text { somewhat transparent growth }\end{array}$ & $+\operatorname{cocci}$ & no growth & $\begin{array}{l}\text { growth partial colour } \\
\text { change }\end{array}$ & $\stackrel{+}{+}$ & no growth \\
\hline $\mathrm{C}$ & thick smooth golden growth & $+\operatorname{rod}$ & whitish yellow & $\begin{array}{l}\text { no growth no colour } \\
\text { change }\end{array}$ & $\begin{array}{c}+ \\
\text { growth }\end{array}$ & transparent \\
\hline $\mathrm{D}$ & $\begin{array}{l}\text { thick White waxy growth } \\
\text { abundant }\end{array}$ & - cocci & No growth & $\begin{array}{l}\text { no growth no colour } \\
\text { change }\end{array}$ & $\begin{array}{c}+ \\
\text { growth }\end{array}$ & no growth \\
\hline $\mathrm{E}$ & $\begin{array}{c}\text { Thick grayish growth smooth } \\
\text { abundant }\end{array}$ & $+\operatorname{rod}$ & no growth & $\begin{array}{c}\text { no growth no colour } \\
\text { change }\end{array}$ & $\begin{array}{c}+ \\
\text { growth }\end{array}$ & spotted red \\
\hline $\mathrm{F}$ & $\begin{array}{l}\text { thick smooth shiny waxy } \\
\text { grayish growth }\end{array}$ & - cocci & pink & $\begin{array}{l}\text { growth complete } \\
\text { colour change }\end{array}$ & $\begin{array}{l}- \text { no } \\
\text { growth }\end{array}$ & purple \\
\hline G & $\begin{array}{l}\text { smooth thick transparent } \\
\text { growth }\end{array}$ & - cocci & pink & $\begin{array}{l}\text { growth } 3 / 4 \text { th colour } \\
\text { change }\end{array}$ & $\begin{array}{c}+ \\
\text { growth }\end{array}$ & blue/violet \\
\hline $\mathrm{H}$ & $\begin{array}{l}\text { thick abundant whitish } \\
\text { growth }\end{array}$ & $-\operatorname{cocci}$ & transparent & $\begin{array}{c}\text { no growth no colour } \\
\text { change }\end{array}$ & $\begin{array}{l}- \text { no } \\
\text { growth }\end{array}$ & ink blue \\
\hline I & $\begin{array}{c}\text { golden growth thick smooth } \\
\text { abundant }\end{array}$ & $+\operatorname{rod}$ & Ink blue & growth colour change & $\begin{array}{c}+ \\
\text { growth }\end{array}$ & brown/ gray \\
\hline
\end{tabular}

Table no. 2 : Results of different biochemical tests

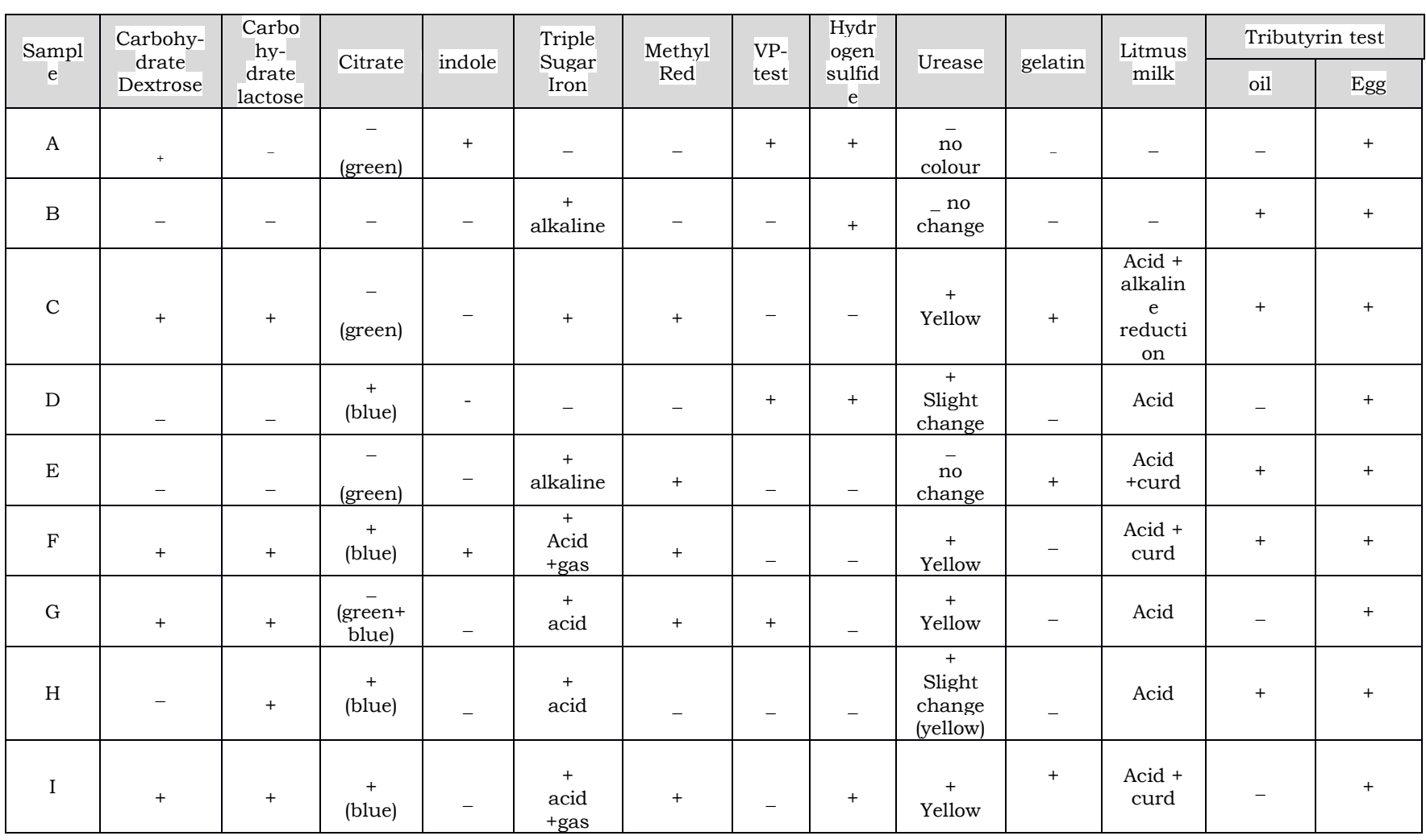

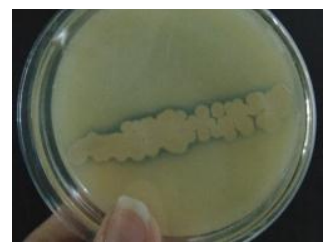

Fig: showing the positive result of tributyrin egg agar test on 